\title{
Review
}

\section{Influence the Fillers Orientation: A Short Review}

\author{
Nabilah Afiqah Mohd Radzuan ${ }^{*}$, Abu Bakar Sulong, ${ }^{1,2}$, Mahendra Rao Somalu1 \\ 1 Fuel Cell Institute, Universiti Kebangsaan Malaysia, 43600 UKM Bangi, Malaysia. \\ 2 Department of Mechanical and Materials Engineering, Faculty of Engineering and Built Environment, \\ Universiti Kebangsaan Malaysia, 43600 Bangi, Selangor, Malaysia. \\ * Correspondence: afiqah@ukm.edu.my
}

\begin{abstract}
Bipolar plates significantly contribute in the development of the polymer electrolyte membrane (PEM) fuel cells technology due to their ability to produce high electrical conductivity based on type of materials used. Mismatching of inappropriate materials and manufacture may lead to the inferior performance of PEM fuel cells. Hence, material development was determined crucial to balance the overall performance of PEM fuels including the mechanical properties and electrical conductivity of the materials. Studies on conductive polymer composites (CPCs) offered filler orientation as an alternative method to enhance the overall performance of bipolar plate. Filler orientations permit an excellent conductivity network formation while controlling the filler alignment based on required applications. This paper reviewed various studies of filler orientations including materials used and methods of manufacture of CPC materials for the effective development of bipolar plate.
\end{abstract}

Keywords: conductive polymer composite; orientation; electrical conductivity.

\section{Introduction}

Polymer electrolyte membrane fuel cell (PEMFC) is a potential power source for various applications due to its low operating temperature, high efficiency, high power density and good impermeability [1,2]. A significant component of the PEMFC is the bipolar plates which account for $80 \%$ of the total stack weight and $45 \%$ of stack cost [3]. Generally, there are two types of bipolar plates used in PEMFCs including metal based bipolar plate and carbon based bipolar plate $[4,5]$. However, the major limitation of metal based bipolar plate is the lack of corrosion resistance which promotes degradation while carbon-based bipolar plate is lack in mechanical properties as the material become more brittle, less durable and more permeable to gases [3,4,6-8].

There are various materials available to develop the bipolar plate including traditional graphite, metallic alloy and graphite-polymer composite $[3,6]$. However, these materials have a major drawback which deteriorates the performance of bipolar plate as a result of imbalance between the electrical conductivity and mechanical properties [3]. Thus, current research trends tend to use conductive polymer composite (CPC) as an alternative material due to its ability to enhance electrical conductivity while maintaining the mechanical properties of the material [9-12]. CPC materials are obtained by mixing the insulating material such as thermoplastic or thermoset material with conductive fillers such as carbon black, carbon nano-tubes (CNTs) and carbon fibre [3,13]. The unique morphology and structure of the conductive pathways within the composite materials are the main parameters that determine the electrical properties of CPCs [14]. However, due to numerous choices of materials, there are still lots of improvement on the bipolar plate performance are required. Commercial bipolar plate is usually developed using graphite $(G)$ materials which have the 
disadvantage in brittleness and difficulty in machining $[3,7,8,15,16]$. As result, a thick bipolar plate is produced which in turn increases the weight of fuel cell stack $[3,8]$.

High electrical conductivity is the key requirement for an excellent bipolar plate. The electrical conductivity is usually measured as a through-plane and in-plane electrical conductivity. However, the obtained electrical conductivity remains inadequate as the through-plane electrical conductivity is generally lower than in-plane electrical conductivity as shown in numerous studies $[7,10,17]$. For example, a study using CNTs/G reinforce epoxy (EP) showed that the electrical conductivities of the through-plane and in-plane conductivity were $180 \mathrm{~S} / \mathrm{cm}$ and $65 \mathrm{~S} / \mathrm{cm}$, respectively [7]. The same trend was also reported using the CF/SG/EP composite materials where the through-plane conductivity $(50.34 \mathrm{~S} / \mathrm{cm})$ was determined lower than in-plane conductivity (69.79 $\mathrm{S} / \mathrm{cm}$ ) [10]. These results explained the deficiency of the overall performance of bipolar plate as a result of low through-plane conductivity. Figure 1 illustrates the mechanism of electron flow in the bipolar plate which determined the through-plane and in-plane conductivities of the plate [7,17]. Yet, none of the studies has achieved these conditions due to some deficiency in conductivity network formations.

Several studies suggested that the electrical conductivity of composite materials often affected by the structural properties of the fillers used in the insulating resin matrix including filler aspect ratio, shape factor and fillers orientations $[3,18,19]$. Filler orientations seem to be an alternative way to improve the electrical conductivity of bipolar plate. For instance, studies based on the multiwalled carbon nano-tubes (MWNTs) revealed the occurrence of network formations at low MWNT content in the bipolar plate due to excellent nano-tubes dispersions [20]. Since 1995, Lux et al. have described the importance of filler distributions, orientation and processing technique in insulating matrix as the orientation of fillers along the basal plane is able to produce higher electrical conductivity in comparison to the perpendicular to basal plane [21,22]. The properties of graphite and CNTs fillers, which have the high aspect ratio exhibited the anisotropic electrical properties that guarantee the high performance in the parallel axial direction [22-26]. However, fillers not necessary have to be in highly anisotropic conditions as studies using the carbon black (CB) particles reported that the electron tunnelling was formed as the CB tends to aggregate [14]. Yet, the electrical conductivity of the composite is usually lower compared to the filler with anisotropic behavior. These results reported while using the $\mathrm{CB}$ particles that eventually decreases the anisotropic of the composite and the overall performance on the composite [22]. Moreover, the efficient and accurate predictions of the filler orientations also very useful to control and design the manufacturing process as inhomogeneity of fillers often leads to lower materials performance [27].
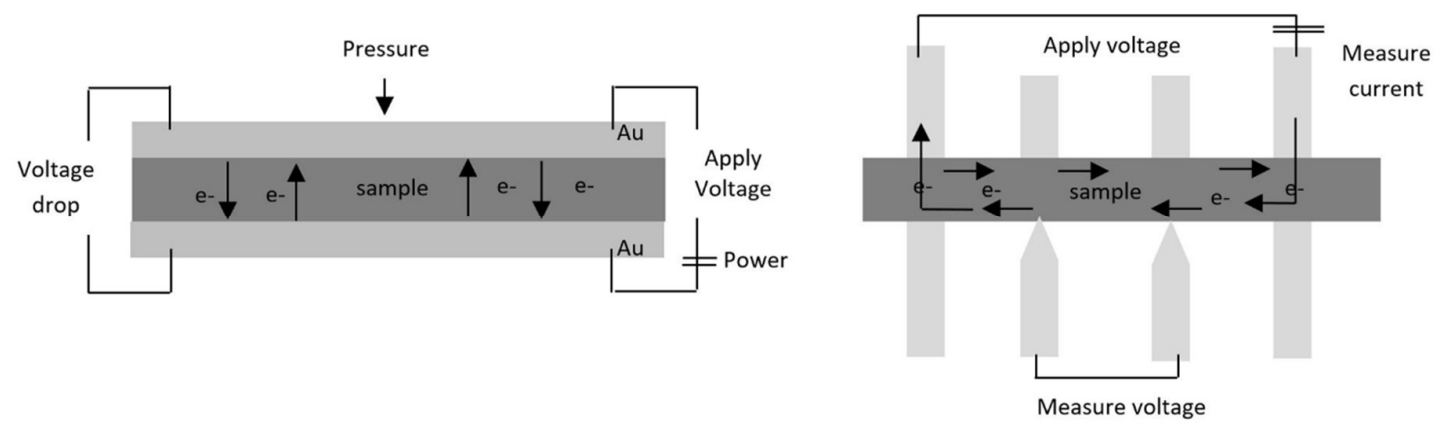

[Figure 1 Illustrations of (a) through-plane conductivity and (b) in-plane conductivity.] 
3 of 12

\section{Development in the processing of composite materials}

The manufacturing process of bipolar plate is the most important factors as it affects both mechanical properties and the electrical conductivity of composite materials. These factors related to the filler orientation, dispersion within the polymer matrix and conductivity network formations in composite materials [3]. In the current research trend, compression moulding or injection moulding technique is usually used to fabricate the bipolar plate. Injection moulding process offers high productivity that aid in massive productive rates and cost reductions. However, the viscosity of the composites increases due to increase in filler loading which harden the manufacturing process.

Therefore, compression molding seems to be an efficient alternative to produce high CPC materials $[8,12]$. Compression molding enables the fillers to retain within the polymer matrix while producing a laminate structure that maximizes the mechanical strength of the composite materials [28]. Studies using the GF/WPVC showed that compression molded sample had better mechanical properties compared to that produced by extrusion process due to low shear stress and low deformations experienced by the composite materials [29]. The high shear stress resulted in higher fibre breakage which lowers the mechanical strength of composite materials. The severe results obtained by Wang et al. using GF/PP composite materials undergoing injection molding process showed that the long fibre (LF) experienced more fibre breakage compared to short fibre. This phenomenon is difficult to compromise as it leads to deterioration in the mechanical properties of composite materials even though shear stress experienced by the fibre enhance the fibre orientations and tensile performance [30]. However, different studies using both long and short fibre of CF/PP composite reported that the longer CF was able to enhance the electrical conductivity of composites due to the earlier formation of conductive pathways [31]. Taipalus et al. explained in detail that the fibre with high aspect ratio was able to form end-to-end contact and led to an excellent conductive network formation. This phenomenon showed that the fibre loading is the key factor in developing excellent conductive pathways since at higher filler loading fibre tends to experience more filler breakage compared to low fibre loading $[3,17]$.

Thus, in order to balance the overall performance of composite materials, current studies applied various manufacturing methods including method to disperse the fibre within the polymer matrix. For instance, Suherman et al. and Kakati et al. used several steps to ensure a homogenous mixture including ball milling technique [22,23]. However, studies reported in 1996 showed that the mechanical properties of composites were improved while using the extrusion process as the fibre tends to orientate its align to the desired orientation [32,33]. This indicated that extrusion is an alternative mixing method which can minimise the processing cost and time. In 2008, Barton et al. applied the extrusion process as the pre-mixing process before undergoing the injection molding process on G/CF reinforced liquid crystal polymer (LCP). This demonstrated that the extrusion process is able to obtain a homogenous mixture even with multiple fillers [34]. Moreover, studies using MWNT/PC showed that the mixing process via extrusion is able to produce a uniformly disperse mixture [20]. It is crucial to determine the suitable mixing and manufacturing processes to acquire maximum electrical conductivity while maintaining the mechanical properties of composite materials. 


\section{Fillers orientations effects on CPC materials performance}

Previous studies reported that the filler orientations aid in the enhancement of mechanical properties and electrical conductivity at the preferential direction. Studies using GF/Wood-PVC composites showed that the align fibre tended to have a higher flexural modulus and flexural strength of $20 \%$ increment compared to the random fibre alignment due to the continuity of fibre to bearing of the applied loads. The experiment reported that the fibre which orientates at $0^{\circ}$ experienced the highest tensile strength compared to fibre that orientates at $45^{\circ}$ and $90^{\circ}$ [29]. Meanwhile, studies using the cotton fibre reinforced geopolymer composites explained that the fibre in horizontal orientations exhibited a higher flexural strength, fracture toughness and compressive strength in contrast to the fibre in vertical orientations as shown in Figure 2 [35]. These are due to the fact that as in vertical orientations, the cotton fibre suffered from detachments and delamination which lowered the composites strength. Moreover, Alomayri et al. (2014) reported the existence of the crack-bridging in the vertical orientation which further lowered the composite strength [35]. Besides, the fibre orientation along the parallel directions showed excellent anisotropic mechanical properties rather than, in the perpendicular direction when using the graphite composites materials [36]. These indicated that the fibre orientations are crucial to determine optimum mechanical properties which can be developed by using the mixing process including an extrusion process.

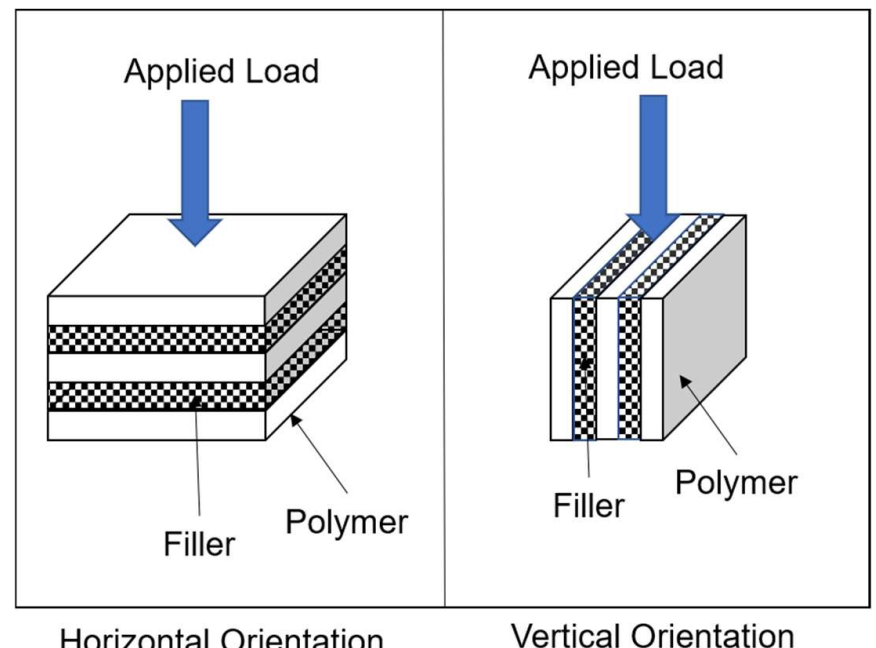

Horizontal Orientation Vertical Orientation

[Figure 2 Schematic drawing of the cotton fibre orientation with respect to applied load.]

Kakati et al. reported that the electrical conductivity of the composite materials changed by the fibres orientation [3,22]. These were showed as at higher CF loading, within 5\% to $9 \%$, the electrical conductivity started to deteriorate due to agglomeration of the fibre in the NG-CB-CF-PF systems [22]. These were due to the fact that, CF has higher aspect ratio compared to other fillers in the system as a result of the fillers orientations in the matrix. The same pattern of electrical conductivity enhancement was reported using synthetic graphite (SG) fillers in liquid crystal polymer (LCP) compared to CF and CB fillers due to the fact that the fillers with high aspect ratio tended to orientate accordingly within the polymer matrix to provide a good electrical pathway [19]. The latest research reported that the fillers with high aspect ratio were used as the secondary fillers as their ability to fill the empty space of the primary fillers within the polymer matrix while developing an electrical network simultaneously [9].These showed that the high aspect ratio fillers have the 
capability to enhance the electrical conductivity of composite materials in many ways. Meanwhile, studies using the MWNTs in polycarbonate (PC) matrix reported that there was no evidence of fibres orientation as MWNT orientated randomly in both perpendicular and parallel to the extrusion directions [20]. Researchers reported that this phenomenon was due to the high aspect ratio and extreme geometry structure of the fibre. Besides, low shear rate and viscosity during the melting and mixing process also the main cause of the fibre to orientate randomly, as low shear stress was transferred onto the fibre. However, these randomly orientated MWNTs seem to be practical in certain applications, in order to enhance the percolation threshold of the composite materials up to $1.5 \mathrm{wt}$ \%, as WMNTs were dispersed evenly in the polymer matrix [20]. These explained that the fibre orientation has the ability to control the mechanical properties and the electrical conductivity based on the applications needs.

\section{Methods to induce fillers orientations}

Since 1997, filler orientation in composite materials has been investigated to enhance materials performance. However, studies often focused on the mechanical properties rather than the overall performance of the composite materials. Thus, current trends showed that filler orientations are able to boost the electrical conductivity while maintaining the mechanical properties of the materials [37]. There were a few methods used to induce the fibre into certain orientations including shear rate, die geometries and filler aspect ratio [24,31,38]. Fibre aspect ratio often related to the filler distributions within the polymer matrix. At low filler loading, filler aspect ratio is the key of filler distributions affecting the conductivity network formations [39]. Moreover, high aspect ratio fillers tended to orientate more compared to low aspect ratio fillers [31].

It has been demonstrated that by introducing a breaker plate as the pre-orientation medium led to higher degrees of fibre orientation compared to traditional slit convergent dies [40]. In 1996, studies reported that the classical dies, later known as convergent dies produced a longitudinal orientation while divergent dies produced elongational deformations which allow the fibre to orientate to the desired orientations [32]. However, near the die walls, the shear deformation force of the fibre to align in longitudinal orientations. These explained the importance of die geometry in order to produce adequate fibre orientations. A study on glass fibre reinforced polypropylene indicated that the introduction of a pre-shearing using a slit die was able to orientate the glass fibre at $0.1{ }^{\mathrm{s}-1}$ pre-shearing for $60 \mathrm{~min}$ [41]. However, different phenomenon were reported when using series sizes of the die gage on WMNT/vinyl ester composites. Fan et al. reported that there are similarities of WMNTs alignment in every micro channel, nano channel and cross section of the cylinder despite differing in gauge sizes due to non-Brownian motion effect to randomise the fibre orientations [24]. Tungjitpornkull et al. (2009) demonstrated that the compression molding was able to orientate fibre in $0^{\circ}$ compared to extrusion technique using the twin-screw extruder. The studies reported that the fibre tended to align $0^{\circ}$ while giving maximum mechanical properties [29].

Besides, studies using the PP/wood-fibre composites reported that the screw speed of 150 rpm produced higher mechanical properties and narrow size distributions compared to $100 \mathrm{rpm}$ and $200 \mathrm{rpm}$. These are due to the better dispersion of the wood-fibre in the composite materials [42]. This strongly explained by the morphology structure of the composite PP/wood-fibre, where the best reaction occurred at $150 \mathrm{rpm}$. Studies using polyethylene glycol as a lubricant able to induce the short fibre into a correct fibre orientation throughout all the die thicknesses influenced by the shear force 
$[20,24,32,41]$. Moreover, Fan et al. reported that the orientations of MWNT remain unchanged after applying the shear force for 24 hours suggesting that the shear flow were permanently generated [24]. The shear stress not only does develop better orientations but also affect the fibre microstructure. Studies using the long glass fibre reinforced polypropylene (LFPP) reported that LFPP experienced fibre breakage which deteriorated the mechanical properties including the tensile properties of composite materials [30]. Besides, an increase in the generated shear force increased the melt viscosity, which in turn increased the fibre addition and resulted in fibres orientation [43,44]. However, a composite mixture with high viscosity may lead to difficulties in processing and formation of voids in the final composite materials [7]. Huang et al. proposed a study on different orientation angles which indicated that at an angle of 00 has the highest shear stress and normal stress compared to $30^{\circ}, 60^{\circ}$ and $90^{\circ}$ of fibre orientations [45]. This demonstrated that the fibre orientation strongly related to shear stress and viscosity of the composite materials.

\section{Measuring the filler orientations}

Measuring the filler orientation is very critical as studies showed that the angle of filler orientation was used in predicting the electrical conductivity of composite materials [31,37]. There are various methods available in measuring the filler orientations in composite materials including direct methods and indirect methods. Direct methods such as SEM, FESEM, AFM, X-CT and more are usually used to visualise the fibre orientations especially for micron size fibres as these are the easiest methods to determine the morphology changes in composite materials [24,30]. For instance, Potschke et al. used the direct methods of SEM, TEM and AFM to observe the fibre alignment in cross section area, perpendicular and parallel to extrusion direction [20]. In additions, the dispersion of fibre in the nano-fibre materials are usually observed using TEM and FESEM. In this observation, the sample is sliced into thin film [46-48]. On the other hand, Dweri et al. used the digital image analysis (MatLab) in cooperating with the direct method of VPSEM to measure the electrical conductivity of the composite materials $[49,50]$. This indicates that the variety of direct methods can be used to observe the filler orientations in the composite materials. Details of fibre orientation measuring methods are summarized in Table 1.

[Table 1 Fibre orientation measuring methods.]

\begin{tabular}{|l|l|l|l|l|}
\hline \multicolumn{1}{|c|}{ Matrix } & \multicolumn{1}{|c|}{ Filler } & \multicolumn{1}{|c|}{$\begin{array}{l}\text { Composite } \\
\text { Processing } \\
\text { method }\end{array}$} & \multicolumn{1}{|c|}{$\begin{array}{c}\text { Orientation } \\
\text { measurement }\end{array}$} & Reference \\
\hline $\begin{array}{l}\text { Polybutadiene } \\
(\text { PB })\end{array}$ & MWNT & Rheology & $\begin{array}{l}\text { Shear } \\
\text { scattering/microscopy } \\
\text { (optical measurement) }\end{array}$ & {$[51]$} \\
\hline Polypropylene & $\begin{array}{l}\text { Graphite } \\
\text { Carbon black }\end{array}$ & $\begin{array}{l}\text { Compression } \\
\text { molding }\end{array}$ & VPSEM & [49,52] \\
\hline Polypropylene & Short fibre & Extrusion & SEM (photograph) & {$[32]$} \\
\hline $\begin{array}{l}\text { Phenol } \\
\text { formaldehyde }\end{array}$ & Graphite & $\begin{array}{l}\text { Compression } \\
\text { molding }\end{array}$ & $\begin{array}{l}\text { SEM (data image } \\
\text { processing) }\end{array}$ & {$[23]$} \\
\hline $\begin{array}{l}\text { Polycarbonate } \\
\text { (PC) }\end{array}$ & MWNTs & Extrusions & $\begin{array}{l}\text { SEM } \\
\text { AFM }\end{array}$ & {$[20]$} \\
\hline
\end{tabular}


4 of 12

\begin{tabular}{|c|c|c|c|c|}
\hline Vinyl ester & Oxidized MWNT & $\begin{array}{l}\text { Micro and nano- } \\
\text { sized channels }\end{array}$ & $\begin{array}{l}\text { TEM } \\
\text { Second order tensor }\end{array}$ & [24] \\
\hline $\begin{array}{l}\text { Polyetherimide } \\
\text { (PEI) }\end{array}$ & Carbon fibre & $\begin{array}{l}\text { Plain weave } \\
\text { (adhesive wear } \\
\text { study) } \\
\text { Compression } \\
\text { molding }\end{array}$ & SEM & [28] \\
\hline $\begin{array}{l}\text { Sheet molding } \\
\text { compounds } \\
\text { (SMC) }\end{array}$ & Glass fibre & Pyrolysis & $\begin{array}{l}\text { Transmission of visible } \\
\text { light } \\
\text { X-ray imaging }\end{array}$ & [46] \\
\hline Polypropylene & $\begin{array}{l}\text { Glass fibre (short } \\
\text { fibre and long } \\
\text { fibre) }\end{array}$ & $\begin{array}{l}\text { Compression } \\
\text { molding }\end{array}$ & $\begin{array}{l}\text { X-ray computed } \\
\text { tomography }(\mathrm{X}-\mathrm{C} \mathrm{T})\end{array}$ & [41] \\
\hline $\begin{array}{l}\text { Poly-ester } \\
\text { Poly-epoxy }\end{array}$ & $\begin{array}{l}\text { Short carbon } \\
\text { fibre }\end{array}$ & $\begin{array}{l}\text { Compression } \\
\text { molding }\end{array}$ & SEM & [13] \\
\hline Polyacrylamide & Short glass fibre & - & $\begin{array}{l}\text { SEM (2D-image analysis) } \\
\text { Fibre orientation } \\
\text { distribution (FOD) }\end{array}$ & [53] \\
\hline $\begin{array}{l}\text { Isophthalic } \\
\text { polyester }\end{array}$ & Glass fibre & $\begin{array}{l}\text { Twisted fibre } \\
\text { yarns (stitching) }\end{array}$ & SEM & [54] \\
\hline Polymers & Short fibre & - & $\begin{array}{l}\text { Fibre length distribution } \\
\text { (FLD) } \\
\text { Fibre orientation } \\
\text { distribution (FOD) }\end{array}$ & [55] \\
\hline $\begin{array}{l}\text { Isotactic } \\
\text { polypropylene }\end{array}$ & Glass fibre & $\begin{array}{l}\text { Extrusions } \\
\text { Injection } \\
\text { molding }\end{array}$ & $\begin{array}{l}\text { Optical microscope }(\mathrm{OM}) \\
\text { observation } \\
\text { SEM } \\
\text { Micro-FTIR }\end{array}$ & [30] \\
\hline $\begin{array}{l}\text { Wood/poly(vinyl } \\
\text { chloride) }\end{array}$ & E-glass fibre & $\begin{array}{l}\text { Extrusions } \\
\text { Compression } \\
\text { molding } \\
\end{array}$ & SEM & [29] \\
\hline Rubber & MWNTs & $\begin{array}{l}\text { Mechanical } \\
\text { mixing } \\
\text { Extrusions }\end{array}$ & $\begin{array}{l}\text { FESEM } \\
\text { WAXD }\end{array}$ & [48] \\
\hline Thermoplastic & Short fibre & $\begin{array}{l}\text { Injection } \\
\text { molding }\end{array}$ & $\begin{array}{l}\text { Second order orientation } \\
\text { tensor }\end{array}$ & [27] \\
\hline Polypropylene & Glass fibre & Extrusions & $\begin{array}{l}\text { Transputer controlled } \\
\text { image analysis }\end{array}$ & [40] \\
\hline Epoxy & $\begin{array}{l}\text { Milled carbon } \\
\text { fibre }\end{array}$ & $\begin{array}{l}\text { Mechanical } \\
\text { mixing } \\
\text { Compression } \\
\text { molding }\end{array}$ & SEM & [10] \\
\hline
\end{tabular}




\begin{tabular}{|l|l|l|l|l|}
\hline $\begin{array}{l}\text { Nylon 6,6 } \\
\text { Polycarbonate }\end{array}$ & Carbon fiber & $\begin{array}{l}\text { Extrusions } \\
\text { Injection } \\
\text { molding }\end{array}$ & $\begin{array}{l}\text { Electrical conductivity } \\
\text { model }\end{array}$ & [18] \\
\hline $\begin{array}{l}\text { Vectra liquid } \\
\text { crystal polymer } \\
(\text { LCP })\end{array}$ & Carbon fibre & $\begin{array}{l}\text { Extrusions } \\
\text { Injection } \\
\text { molding }\end{array}$ & Optical microscope (OM) & {$[56]$} \\
\hline $\begin{array}{l}\text { Geopolymer } \\
\text { matrix }\end{array}$ & Cotton fabric & Layer & SEM method & {$[45]$} \\
\hline Polypropylene & $\begin{array}{l}\text { Single } \\
\text { wall carbon } \\
\text { nanotube } \\
\text { (SWCNT) }\end{array}$ & $\begin{array}{l}\text { Tensile stress- } \\
\text { stain }\end{array}$ & $\begin{array}{l}\text { Finite element maTRAN) } \\
\text { (PATR }\end{array}$ & [35] \\
\hline
\end{tabular}

Meanwhile, indirect method seems to be an effective method to quantify the amount of fibre alignment produced and to determine the fibre misalignment in the composite materials [38]. X-ray diffraction (XRD) is used extensively for this purpose where the graphitic plane azimuthal diffraction is measured in degrees and used to characterize the fibre orientation. For instance, the fibre alignment was reported as a vapour grew carbon in the preferred direction $\left(0^{\circ}\right)$. It is critical to note that the intensity of the diffraction pattern at high angles is generally very low while the intensity at $0^{\circ}$ is generally very high as shown in a few studies [38,57]. In addition, several studies investigated the fibre orientation behaviour in composite materials using the wide-angle X-ray diffraction (WAXD) $[48,56]$. For example, Kim et al. determined that the CNTs were aligned in the $\mathrm{x}$-direction as expected when measured using this method. Moreover, WAXD is able to determine the degree of orientation at different CNT loading. For instance, at $5 \mathrm{wt} \%$. the degree of orientation is lower compared to 30 wt\%. [48]. This behaviour is due to the fact that at higher filler loading a better network of conductivity was formed resulting from better CNT orientation within the polymer matrix. This demonstrated that the selection of technique for measuring the fibre orientation is very crucial for effective investigation of the composite materials.

\section{Conclusions}

The development of conductive polymer composite (CPC) materials is very important due to the fact that these materials directly influenced the performance of PEM fuel cell. Fibre orientations are the key factor to enhance both the mechanical properties and electrical conductivity of CPC materials. Extrusion process is the best method to induce the fibre into the desired orientations. Based on the discussion above, the extrusion process is able to induce orientations as it possesses an adequate shear rate and controllable die geometries. Meanwhile, the scanning electron microscope is a common method in determining the fibre orientation compared to indirect methods.

Acknowledgments: The authors gratefully thank the Universiti Kebangsaan Malaysia for the financial support to complete this study under grant number MI-2017-004.

Author Contributions: Nabilah Afiqah Mohd Radzuan designed, conceived and wrote the paper. Abu Bakar Sulong financially supported for this research and finalized the manuscript. Mahendra Rao Somalu contribute in editing and finalized the manuscript.

Conflicts of Interest: The authors declare no conflict of interest. 
6 of 12

\section{References}

[1] Rosli, R.E.; Sulong, A.B.; Daud, W.R.W.; Zulkifley, M.A.; Rosli, M.I.; Majlan, E.H., et al. The design and development of an HT-PEMFC test cell and test station. Int J Hydrogen Energy 2018, 1-9, doi:10.1016/j.ijhydene.2018.01.174.

[2] González-Espasandín Ó.; Leo, T.J.; Raso, M.A.; Navarro, E. Direct methanol fuel cell (DMFC) and H2 proton exchange membrane fuel (PEMFC/H2) cell performance under atmospheric flight conditions of Unmanned Aerial Vehicles. Renew Energy, 2019; 130:762-73, doi:https://doi.org/10.1016/j.renene.2018.06.105.

[3] Antunes, R.A.; de Oliveira, M.C.L.; Ett, G.; Ett, V. Carbon materials in composite bipolar plates for polymer electrolyte membrane fuel cells: A review of the main challenges to improve electrical performance. J Power Sources, 2011, 196:2945-61, doi:http://dx.doi.org/10.1016/j.jpowsour.2010.12.041.

[4] Du, C.; Ming, P.; Hou, M.; Fu, J.; Fu, Y.; Luo, X. The preparation technique optimization of epoxy/compressed expanded graphite composite bipolar plates for proton exchange membrane fuel cells. J Power Sources, 2010, 195:5312-9, doi:http://dx.doi.org/10.1016/j.jpowsour.2010.03.005.

[5] Radzuan, N.A.M.; Sulong, A.B.; Somalu, M.R. Effects of Die Configuration on the Electrical Conductivity of Polypropylene Reinforced Milled Carbon Fibers : An Application on a Bipolar Plate . Polymers, 2018, 10:558, doi:10.3390/polym10050558.

[6] Hwang, I.U.; Yu, H.N.; Kim, S.S.; Lee, D.G.; Suh, J.D.; Lee, S.H. Bipolar plate made of carbon fiber epoxy composite for polymer electrolyte membrane fuel cells. J Power Sources, 2008; 184:90-4, doi:http://dx.doi.org/10.1016/j.jpowsour.2008.05.088.

[7] Suherman, H.; Sulong, A.B.; Sahari, J. Effect of the compression molding parameters on the in-plane and through-plane conductivity of carbon nanotubes/graphite/epoxy nanocomposites as bipolar plate material for a polymer electrolyte membrane fuel cell. Ceram Int, 2013; 39:1277-84, doi:http://dx.doi.org/10.1016/j.ceramint.2012.07.059.

[8] Taherian, R. A review of composite and metallic bipolar plates in proton exchange membrane fuel cell: Materials, fabrication, and material selection. J Power Sources, 2014, 265:370-90, doi:10.1016/j.jpowsour.2014.04.081.

[9] Radzuan, N.A.M.; Zakaria, M.Y; Sulong, A.B.; Sahari, J. The effect of milled carbon fibre filler on electrical conductivity in highly conductive polymer composites. Compos Part B Eng, 2017, 110:153-60, doi:10.1016/j.compositesb.2016.11.021.

[10] Zakaria, M.Y.; Sulong, A.B.; Sahari, J.; Suherman, H. Effect of the addition of milled carbon fiber as a secondary filler on the electrical conductivity of graphite/epoxy composites for electrical conductive material. Compos Part B Eng, 2015, 83:75-80, doi:http://dx.doi.org/10.1016/j.compositesb.2015.08.034.

[11] Balogun, Y.A.; Buchanan, R.C. Enhanced percolative properties from partial solubility dispersion of filler phase in conducting polymer composites (CPCs). Compos Sci Technol, 2010, 70:892-900, doi:DOI 10.1016/j.compscitech.2010.01.009.

[12] Sulong, A.B.; Ramli, M.I.; Hau, S.L.; Sahari, J.; Muhamad, N.; Suherman, H. Rheological and mechanical properties of carbon nanotube/Graphite/SS316L/polypropylene nanocomposite for a conductive polymer composite. Compos Part B Eng, 2013, 50:54-61, doi:http://dx.doi.org/10.1016/j.compositesb.2013.01.022.

[13] Feller, J.F.; Linossier, I.; Grohens, Y. Conductive polymer composites: comparative study of poly(ester)short carbon fibres and poly(epoxy)-short carbon fibres mechanical and electrical properties. Mater Lett, 
2002, 57:64-71, doi:Pii S0167-577x(02)00700-0Doi 10.1016/S0167-577x(02)00700-0.

[14] Feller, J.F.; Chauvelon, P.; Linossier, I.; Glouannec, P. Characterization of electrical and thermal properties of extruded tapes of thermoplastic conductive polymer composites (CPC). Polym Test, 2003, 22:831-7, doi:Doi 10.1016/S0142-9418(03)00020-5.

[15] Lee, J.H.; Jang, Y.K.; Hong, C.E.; Kim, N.H.; Li, P.; Lee, H.K. Effect of carbon fillers on properties of polymer composite bipolar plates of fuel cells. J Power Sources, 2009, 193:523-9, doi:http://dx.doi.org/10.1016/j.jpowsour.2009.04.029.

[16] Mathur, R.B.; Dhakate, S.R.; Gupta, D.K.; Dhami, T.L.; Aggarwal, R.K. Effect of different carbon fillers on the properties of graphite composite bipolar plate. J Mater Process Technol, 2008, 203:184-92, doi:http://dx.doi.org/10.1016/j.jmatprotec.2007.10.044.

[17] Suherman, H.; Sahari, J.; Sulong, A.B. Effect of small-sized conductive filler on the properties of an epoxy composite for a bipolar plate in a PEMFC. Ceram Int, 2013, 39:7159-66, doi:http://dx.doi.org/10.1016/j.ceramint.2013.02.059.

[18] Clingerman, M.L.; King, J.A.; Schulz, K.H.; Meyers, J.D. Evaluation of electrical conductivity models for conductive polymer composites. J Appl Polym Sci, 2002, 83:1341-56, doi:10.1002/app.10014.

[19] Barton, R.L.; Keith, J.M.; King, J.A. Development and modeling of electrically conductive carbon filled liquid crystal polymer composites for fuel cell bipolar plate applications. J New Mater Electrochem Syst, 2007, 10:225.

[20] Pötschke, P.; Bhattacharyya, A.R.; Janke, A. Melt mixing of polycarbonate with multiwalled carbon nanotubes: microscopic studies on the state of dispersion. Eur Polym J, 2004, 40:137-48, doi:http://dx.doi.org/10.1016/j.eurpolymj.2003.08.008.

[21] Lux, F. Models proposed to explain the electrical conductivity of mixtures made of conductive and insulating materials. J Mater Sci, 1993, 28:285-301, doi:10.1007/BF00357799.

[22] Kakati, B.K.; Sathiyamoorthy, D.; Verma, A. Semi-empirical modeling of electrical conductivity for composite bipolar plate with multiple reinforcements. Int J Hydrogen Energy, 2011, 36:14851-7, doi:http://dx.doi.org/10.1016/j.ijhydene.2011.02.136.

[23] Kakati, B.K.; Yamsani, V.K.; Dhathathreyan, K.S.; Sathiyamoorthy, D.; Verma, A. The electrical conductivity of a composite bipolar plate for fuel cell applications. Carbon N Y, 2009, 47:2413-8, doi:http://dx.doi.org/10.1016/j.carbon.2009.04.034.

[24] Fan, Z.; Advani, S.G. Characterization of orientation state of carbon nanotubes in shear flow. Polymer (Guildf), 2005, 46:5232-40, doi:http://dx.doi.org/10.1016/j.polymer.2005.04.008.

[25] Wang, S.F.; Ogale, A.A. Simulation of percolation behavior of anisotropic short-fiber composites with a continuum model and non-cubic control geometry. Compos Sci Technol, 1993, 46:389-98, doi:http://dx.doi.org/10.1016/0266-3538(93)90184-I.

[26] Qi, L.; Ju, L.; Zhou, J. Tensile Properties of 2D-Cf/Mg Composite Fabricated by Liquid-solid Extrusion Following Vacuum Pressure Infiltration. Procedia Eng, 2014, 81:1577-82, doi:http://dx.doi.org/10.1016/j.proeng.2014.10.193.

[27] Agboola, B.O.; Jack, D.A.; Montgomery-Smith, S. Effectiveness of recent fiber-interaction diffusion models for orientation and the part stiffness predictions in injection molded short-fiber reinforced composites. Compos Part A Appl Sci Manuf, 2012, 43:1959-70, doi:http://dx.doi.org/10.1016/j.compositesa.2012.06.015.

[28] Sharma, M.; Rao, I.M.; Bijwe, J. Influence of orientation of long fibers in carbon fiber-polyetherimide composites on mechanical and tribological properties. Wear, 2009, 267:839-45, 
8 of 12

doi:http://dx.doi.org/10.1016/j.wear.2009.01.015.

[29] Tungjitpornkull, S.; Sombatsompop N. Processing technique and fiber orientation angle affecting the mechanical properties of E-glass fiber reinforced wood/PVC composites. J Mater Process Technol, 2009, 209:3079-88, doi:http://dx.doi.org/10.1016/j.jmatprotec.2008.07.021.

[30] Wang, J.; Geng, C.; Luo, F.; Liu, Y.; Wang, K.; Fu, Q. Shear induced fiber orientation, fiber breakage and matrix molecular orientation in long glass fiber reinforced polypropylene composites. Mater Sci Eng A, 2011, 528:3169-76, doi:http://dx.doi.org/10.1016/j.msea.2010.12.081.

[31] Taipalus, R.; Harmia, T.; Zhang, M.Q.; Friedrich, K. The electrical conductivity of carbon-fibre-reinforced polypropylene/polyaniline complex-blends: experimental characterisation and modelling. Compos Sci Technol, 2001, 61:801-14, doi:http://dx.doi.org/10.1016/S0266-3538(00)00183-4.

[32] Ausias, G.; Jarrin, J.; Vincent, M. Optimization of the tube-extrusion die for short-fiber-filled polymers. Compos Sci Technol, 1996, 56:719-24, doi:http://dx.doi.org/10.1016/0266-3538(96)00012-7.

[33] Nakayama, Y.; Takeda, E.; Shigeishi, T.; Tomiyama, H.; Kajiwara, T. Melt-mixing by novel pitched-tip kneading disks in a co-rotating twin-screw extruder. Chem Eng Sci, 2011, 66:103-10, doi:http://dx.doi.org/10.1016/j.ces.2010.10.022.

[34] Barton, R.L.; Keith, J.M.; King, J.A. Electrical conductivity modeling of multiple carbon fillers in liquid crystal polymer composites for fuel cell bipolar plate applications. J New Mater Electrochem Syst, 2008, $11: 181$.

[35] Alomayri, T.; Shaikh, F.U.A.; Low, I.M. Effect of fabric orientation on mechanical properties of cotton fabric reinforced geopolymer composites. Mater Des, 2014, 57:360-5, doi:http://dx.doi.org/10.1016/j.matdes.2014.01.036.

[36] Panaitescu, D.M.; Gabor, R.A.; Nicolae, C.A.; Ghiurea, M.; Mihailescu, M.; Grigorescu, R.M. Influence of melt processing induced orientation on the morphology and mechanical properties of poly(styrene-bethylene/butylene-b-styrene) block copolymers and their composites with graphite. Mater Des, 2014, 64:694-705, doi:http://dx.doi.org/10.1016/j.matdes.2014.08.049.

[37] Radzuan, N.A.M.; Sulong, A.B.; Sahari, J. A review of electrical conductivity models for conductive polymer composite. Int J Hydrogen Energy, 2017, 42:9262-73, doi:http://dx.doi.org/10.1016/j.ijhydene.2016.03.045.

[38] Kuriger, R.J.; Alam, M.K.; Anderson, D.P.; Jacobsen, R.L. Processing and characterization of aligned vapor grown carbon fiber reinforced polypropylene. Compos Part A Appl Sci Manuf, 2002, 33:53-62 doi:http://dx.doi.org/10.1016/S1359-835X(01)00070-7.

[39] Taherian, R.; Hadianfard, M.J.; Golikand, A.N. Manufacture of a polymer-based carbon nanocomposite as bipolar plate of proton exchange membrane fuel cells. Mater Des, 2013, 49:242-51, doi:http://dx.doi.org/10.1016/j.matdes.2013.01.058.

[40] Hine, P.J.; Davidson, N.; Duckett, R.A.; Ward, I.M. Measuring the fibre orientation and modelling the elastic properties of injection-moulded long-glass-fibre-reinforced nylon. Compos Sci Technol, 1995, 53:125-31, doi:http://dx.doi.org/10.1016/0266-3538(95)00011-9.

[41] Köpplmayr, T.; Milosavljevic, I.; Aigner, M.; Hasslacher, R.; Plank, B.; Salaberger, D. Influence of fiber orientation and length distribution on the rheological characterization of glass-fiber-filled polypropylene. Polym Test, 2013, 32:535-44, doi:http://dx.doi.org/10.1016/j.polymertesting.2013.02.002.

[42] Zhang, Z-X.; Gao, C.; Xin, Z.X.; Kim, J.K. Effects of extruder parameters and silica on physico-mechanical and foaming properties of PP/wood-fiber composites. Compos Part B Eng, 2012, 43:2047-57, doi:http://dx.doi.org/10.1016/j.compositesb.2012.01.047. 
9 of 12

[43] Wood, J.R.; Zhao, Q.; Wagner, H.D. Orientation of carbon nanotubes in polymers and its detection by Raman spectroscopy. Compos Part A Appl Sci Manuf, 2001, 32:391-9, doi:http://dx.doi.org/10.1016/S1359835X(00)00105-6.

[44] Unverfehrt, A.; Rehage, H. Deformation, Orientation and Bursting of Microcapsules in Simple Shear Flow: Wrinkling Processes, Tumbling and Swinging Motions. Procedia IUTAM, 2015, 16:12-21. doi:http://dx.doi.org/10.1016/j.piutam.2015.03.003.

[45] Huang, J.; Rodrigue, D. The effect of carbon nanotube orientation and content on the mechanical properties of polypropylene based composites. Mater Des, 2014, 55:653-63, doi:http://dx.doi.org/10.1016/j.matdes.2013.10.039.

[46] Massardier-Nageotte, V.; Maazouz, A.; Peix, G.; Bres, S. Methodologies for the characterisation of glass fibre orientation and distribution in large components moulded from sheet molding compounds (SMC). Polym Test, 2003, 22:867-73, doi:http://dx.doi.org/10.1016/S0142-9418(03)00023-0.

[47] Xiao, K.Q.; Zhang, L.C.; Zarudi, I. Mechanical and rheological properties of carbon nanotube-reinforced polyethylene composites. Compos Sci Technol, 2007, 67:177-82, doi:http://dx.doi.org/10.1016/j.compscitech.2006.07.027.

[48] Kim, Y.A.; Hayashi, T.; Endo, M.; Gotoh, Y.; Wada, N.; Seiyama, J. Fabrication of aligned carbon nanotube-filled rubber composite. Scr Mater, 2006, 54:31-5, doi:http://dx.doi.org/10.1016/j.scriptamat.2005.09.014.

[49] Dweiri, R.; Sahari, J. Computer simulation of electrical conductivity of graphite-based polypropylene composites based on digital image analysis. J Mater Sci, 2007, 42:10098-102, doi:10.1007/s10853-007-2092$\mathrm{x}$.

[50] Dweiri, R.; Sahari, J. Microstructural image analysis and structure-electrical conductivity relationship of single- and multiple-filler conductive composites. Compos Sci Technol, 2008, 68:1679-87, doi:http://dx.doi.org/10.1016/j.compscitech.2008.02.006.

[51] Hobbie, E.K.; Wang, H.; Kim, H.; Lin-Gibson, S.; Grulke, E.A. Orientation of carbon nanotubes in a sheared polymer melt. Phys Fluids, 2003, 15:1196-202, doi:doi:http://dx.doi.org/10.1063/1.1562161.

[52] Dweiri, R.; Sahari, J. Electrical properties of carbon-based polypropylene composites for bipolar plates in polymer electrolyte membrane fuel cell (PEMFC). J Power Sources, 2007, 171:424-32, doi:http://dx.doi.org/10.1016/j.jpowsour.2007.05.106.

[53] Eberhardt, C.; Clarke, A.; Vincent, M.; Giroud, T.; Flouret, S. Fibre-orientation measurements in shortglass-fibre composites-II: a quantitative error estimate of the 2D image analysis technique. Compos Sci Technol, 2001, 61:1961-74, doi:http://dx.doi.org/10.1016/S0266-3538(01)00106-3.

[54] Solaimurugan, S.; Velmurugan, R. Influence of in-plane fibre orientation on mode I interlaminar fracture toughness of stitched glass/polyester composites. Compos Sci Technol, 2008, 68:1742-52, doi:http://dx.doi.org/10.1016/j.compscitech.2008.02.008.

[55] Fu, S-Y.; Lauke, B. Effects of fiber length and fiber orientation distributions on the tensile strength of short-fiber-reinforced polymers. Compos Sci Technol, 1996, 56:1179-90, doi:http://dx.doi.org/10.1016/S0266-3538(96)00072-3.

[56] Wang, Z.; Fan, X.; Wang, K.; Deng, H.; Chen, F.; Fu, Q. Fabrication of polypropylene/carbon nanotubes composites via a sequential process of (rotating solid-state mixing)-plus-(melt extrusion). Compos Sci Technol, 2011, 71:1397-403, doi:http://dx.doi.org/10.1016/j.compscitech.2011.05.012.

[57] Kuriger, R.J.; Alam, M.K.; Anderson, D.P. Strength prediction of partially aligned discontinuous fiberreinforced composites. J Mater Res, 2001, 16:226-32, doi:10.1557/JMR.2001.0035. 